\title{
Back to the future with IATA NDC? Critical turning points in the history of airline distribution
}

\author{
Stephan Bingemer
}

\begin{abstract}
Purpose - The International Air Transport Association (IATA) New Distribution Capability (NDC) standard aims at modernising the airline distribution landscape. It has supported the spread of Direct Connects by providing a common standard for linking airlines to travel agencies. The purpose of this paper is to analyse the historical development of airline distribution and to derive implications for the future.

Design/methodology/approach - This paper follows the approach of Yeoman and McMahon-Beattie (2017) in providing a chronological account based on published research.

Findings - Direct Connects are discussed to be a step back in the evolution of the distribution landscape because they foster disaggregation. An analysis of the history of distribution finds that a comparison of Direct Connects to the early stages of computer reservation system technology falls short to recognise the tremendous technological and market changes connected to the internet, cloud computing and the rise of low-cost carriers. Moreover, drawing on the seminal article by Anderson and Tushman (1990) on technical discontinuities and dominant designs, the current state of the distribution landscape is characterised to be an era of ferment that is driven by design competition and that might end up in a new dominant design.

Originality/value - The originality of this paper lies in a critical review of the turning points of distribution. By reviewing the past developments, the paper sheds light on the contribution that IATA NDC and Direct Connect technology might deliver to the field of airline distribution.
\end{abstract}

Keywords History, Airlines, Distribution, IATA NDC, GDS, Direct connect

Paper type Research paper

\section{Introduction}

Distribution has been a key process to airlines since decades ago (Sismanidou et al., 2009). Airline distribution is focussed on delivering the airlines' offer (in terms of fares, schedules, availabilities and ancillary services) to the travel agent or customer (Tyagi, 2014).

Three major global distribution systems (GDS), Amadeus, Sabre and Travelport, dominate today's airline distribution landscape (Sismanidou et al., 2009). Given this oligopoly, the issue of distribution cost has become a major battlefield for airlines after having successfully forced travel agent commissions to zero (or close to zero) in many countries (Field and O'Toole, 2004; Hill, 2016). In a real-life example of KLM, the study of Bießlich et al. (2018) indicates that commercial and distribution cost for KLM account for approximately EUR 300m, being higher than, e.g., crew cost. Given the growing relevance of the digital customer, providing products tailored to customer needs is perceived as a key to escape the commodity trap. In consequence, full service carriers (FSC) are seeking for possibilities to gain back control over their product offer from the GDS and to gain additional customer information that allows them to create an outstanding customer journey. In contrast to this, low-cost carriers (LCC) are independent in selling their offers as they are (with minor exceptions) not present in the GDS world. Thus, they have much more possibilities to create ancillary products interesting to their customers. The case of LCC shows that a GDS is per se not needed to sell airline offers.
Stephan Bingemer is Professor at the International School of Management (ISM), Dortmund, Germany.

Received 23 May 2018 Revised 31 August 2018 Accepted 2 September 2018

(C) Stephan Bingemer. Published in Journal of Tourism Futures. Published by Emerald Publishing Limited. This article is published under the Creative Commons Attribution (CC BY 4.0) licence. Anyone may reproduce, distribute, translate and create derivative works of this article (for both commercial and non-commercial purposes), subject to full attribution to the original publication and authors. The full terms of this licence may be seen at http://creativecommons.org/ licences/by/4.0/legalcode 
While there is a long-standing debate in the industry on the value added by GDS, it is still dominating the airline distribution landscape (Schulz, 1996; French, 1998; Brownlow, 2006; Quinby, 2009; Jonas, 2013; Gnutzmann and Spiewanowski, 2016). Researchers have long predicted the end of the GDS era (Alamdari and Mason, 2006; Sismanidou et al., 2009; Carey et al., 2012) but for decades, their position was unchallenged.

The introduction of Direct Connects and the new International Air Transport Association (IATA) distribution standard NDC have brought disruption into the airline distribution landscape. It was American Airlines, the historic root of the Sabre GDS, which shook the US travel agency market in 2011 by announcing its first Direct Connect bypassing the classic GDS structure (Bilotkach et al. , 2014). Four years later, Lufthansa Group, one of the founders of the Amadeus GDS, followed a similar approach in Europe and triggered a huge debate whether Direct Connects lead to information asymmetry and disaggregation of the efficient GDS structures (Gnutzmann and Spiewanowski, 2016).

Given the historic relation between airlines and the GDS, it is worthwhile to analyse how history shapes the future of distribution. Analysing how history is shaping the future is a well-known practice (Alonso, 2010). We perform a critical turning point analysis of airline distribution, drawing on the methodology proposed by Yeoman and McMahon-Beattie (2017). We analyse a chronological account of all issues of the Journal of Air Transport Management from 1994 to 2018 that cover the topic of airline distribution. Different to Yeoman and McMahon-Beattie (2017) who have drawn their analysis fundamentally on articles from the Journal of Revenue and Pricing Management, we enrich our chronological account with articles from other journals. In doing so, we recognise that a full coverage of the field of distribution is almost impossible by reviewing only one single journal source. We aim to looking into the past as a representation of the future (Yeoman and McMahon-Beattie, 2017). In the discussion section, the presented turning points are related to the emergence of dominant designs drawing on Anderson and Tushman (1990).

\section{Turning point 1: entry into the Jet Era and Airline Deregulation Act}

The main driver of airline distribution technology is for sure the exponential growth in passenger volume initiated by the advent of modern jet aircraft, the prospering post-war economy and the deregulation of air traffic (Debbage and Delk, 2001). Oxley and Jain (2015) claim that between 1950 and 1970, global air passenger traffic increased over 10 per cent per year whilst cost of jet travel were brought down by an average of 5 per cent a year. The Boeing 707 and the McDonald-Douglas DC-8 can be considered the first successful commercial jet aircraft with a capacity of approximately 175 seats (Schmitt and Gollnick, 2016).

Before automation, airline reservation was a complex process (Sion et al., 2013). Travel agents needed to look up the schedule of each airline, search for the most convenient connection, call the airline reservation department to gain availability and fare information and enter a preliminary reservation. Afterwards, they needed to go back to the customer and confirm the selection. Finally, the airline reservation department was called once again to book the ticket (Sion et al., 2013).

We conclude that the growth in air traffic volume combined with the strong need to increase efficiency in order to keep control over the operational processes paved the way for the development of airline reservation systems (ARS).

\section{Turning point 2: introduction of ARS}

American Airlines, in the search for an approach to automate its processes, was teaming-up with IBM to create the first ARS in 1964 (Kärcher, 1996). American Airlines named the project "SemiAutomated Business Research Environment (Sabre)" (Boyd, 2006; Sabre, 2018). The system has been designed to increase efficiency in passenger sales, seat inventory control, maintenance and retrieval of passenger records. It took six years to build the largest commercial data processing system in existence, at that time (Plugge and Perry, 1961). The hardware consisted of a duplexed system of two IBM 7090 mainframes (Sabre, 2018). This system was supposed to 
automate the daily reservation processes with the exception of the personal contact to the customer (Plugge and Perry, 1961). The system was built in a way that the availability of current, detailed and summarised data could be extracted for the airline's management (Plugge and Perry, 1961).

The fact that the GDS developed out of the ARS is key to understanding the overall historical context of the ongoing airline distribution debate. As ARS are - up to now - the most important part of an airline system, airlines face enormous hurdles in applying modern technology approaches in distribution. The ARS (being the technological point of departure of the GDS), have been invented in the USA in the 1960s, 30 years before the advent of the internet. In consequence, the minimal viable product of the GDS was inspired by standards of that time (i.e. both, ARS and GDS, were not built for communication in the internet era).

\section{Turning point 3: era of the CRS - extending the ARS for the use of travel agents}

Apart from operational airline processes, the rise of passenger volumes was also a challenge for airline ticket sales (Plugge and Perry, 1961). Airlines so far sold tickets via their airline ticket office or city ticket offices (ATO/CTO). It was the logical next step to make travel agencies book airline flights not via phone but via the ARS.

In the 1970s, airlines began modifying their ARS to allow travel agents to access their systems whilst filtering data and functionalities that should be accessible only to airline staff (Sion et al., 2013). This development step represents the birth of the computerised reservation system (CRS), an extension of the ARS with the purpose to increase airline sales (Kaplan and Dayton, 1988). Through a CRS, a travel agent was not restricted on the airline that connected them to the CRS but they could see all airlines connected to the airline that provided the CRS. Through a CRS, the travel agent was able to access information on flight schedules, fares and seat availability. It also allowed making reservations and issue tickets (Tyagi, 2014).

We define the before mentioned "extended ARS" to be the computerised reservation system (CRS). This is in contradiction with the substitutional use of the terms CRS and GDS, but we believe that the proposed distinction based on the chronical account better reflects the historic stages of distribution technology development. Of course, the other US airlines developed similar CRS systems to American Airline's Sabre. United Airlines developed Apollo, Transworld Airlines launched PARS, Delta Airlines launched DATAS II and Continental Airlines launched System One (Sion et al., 2013). The reason for this was that each CRS provided a biased display favouring the CRS provider. Moreover, the carrier providing the CRS usually received over-proportional booking shares due to the halo effect (Kaplan and Dayton, 1988). CRS providers could charge CRS rental or usage fees to travel agencies and collect booking fees for each flight segment hosted in their system for another airline (Smith et al., 2001).

As every carrier strived for a proprietary CRS to foster its own airline ticket sales, complexity increased. The fact that there was a different CRS provided from each airline lead to a lack of consistency.

\section{Turning point 4: formation of GDS}

The GDS evolved out of the CRS in the 1980s (Sion et al., 2013). The transition from CRS to GDS is not of technological nature but of commercial nature. When CRS technology services were put into autonomous technology companies distinct from the airline structures, this represented the starting point of the GDS. In their (now) neutral role, providing services to all hosted airlines and travel agencies, the offer display was of key relevance. In order to display offers from different airlines, the GDS needed a common base to provide comparison. Travel time, schedule and net fare were the main search parameters selected (Tyagi, 2014). This is worthwhile mentioning, as these results in limitations within the GDS environment until today. In a GDS environment, a search for Wi-Fi on board cannot be performed in the core system as the system was designed in times when Wi-Fi was an unpredictable future. However, this historical perspective allows understanding why this development gap is persisting. 
In Europe, the evolution spilled over from the USA in the mid-1980s but went operational in the 1990s. Lufthansa, SAS Scandinavian Air Services, Air France and Iberia formed Amadeus Global Travel Distribution in 1987 (Kärcher, 1996), providing a system that is derived from Continental Airline's System One. Also in 1987, British Airways, Swiss Air, KLM and Alitalia chose to work on Galileo, a system based on United's Apollo (Sion et al., 2013). The historical roots of the GDS explain their current geographical focus with Sabre being the dominating player in the Americas whilst Amadeus is dominating Europe. The fact that Amadeus started around 25 years later than competitor Sabre might explain why Amadeus is perceived more innovative concerning some features.

The first appearance of the internet at that time is still lying in the future. The GDS are quickly expanding and starting to conquer the European market.

\section{Turning point 5: birth and diffusion of the internet}

British scientist Tim Berners-Lee invented the World Wide Web in 1989 (CERN, 2018). However, it took until the 2000s for the World Wide Web to achieve over $300 \mathrm{~m}$ users equalling to 5 per cent of the world population (Internet World Stats, 2018). In January 2018, more than 4,157m users equalling 54 per cent of the world population have access to the internet (Internet World Stats, 2018). The internet has been an important change driver in the airline industry as it created a new direct sales channel that reached broad acceptance in the marketplace. Different to other direct sales channels such as ATO, CTO and call centres, this channel was enabling self-servicing via the internet. The availability of this new direct sales channel was remarkable from different perspectives.

First, it brought down direct sales cost for airlines, as there was no personal interaction involved (Takač et al., 2006). Given the availability of a sales channel with a lower cost structure, the airlines got back into the position of being capable to cope with a huge airline sales volume on their own. Moreover, by growing their online channel shares to around 30 per cent of the sales volume, airlines got back some control of their distribution processes and were able to create offers fitted to those new channels without being hindered by technological hurdles from the GDS domain.

Second, in online sales channels, the customer is steering the search and booking process on his own, leading to a superior customer experience through convenience and control. The study of Duch-Brown et al. (2017) supports that consumers do profit more than firms from e-commerce. By optimising the user experience and conversion rates for their websites, airlines built significant knowledge in online sales and marketing. This knowledge grew their awareness for the existing technological gap between GDS distribution and direct online distribution. Put in other words, the capabilities implemented on airline websites increased the expectation level towards the GDS.

Third, from a technological standpoint, the internet itself highlighted a shift from a mainframe-dominated central server architecture paradigm to a distributed network paradigm (Akin, 2018). Of course, this challenged the concept of one singular place (i.e. the GDS) that is needed to for aggregation and data storage purposes.

Concluding, the advent of the internet was not purely about invention and diffusion of a new technology. The advent of the internet also influenced the perception of the users, altering the market needs. Moreover, it provided airlines with a direct sales channel that was capable to service massive passenger volumes in an efficient and quick manner, convenient to their customers.

\section{Turning point 6: the rise of LCC and direct sales growth}

The invention of the internet and the liberalisation of air traffic are important drivers of the success of LCC. The low-cost model was invented in the US market by Pacific Southwest Airlines and successfully brought to mainstream by Southwest in 1971 (Decker, 2004; Field, 2016). In Europe, Ryanair adopted the low-cost model in 1992 and Easyjet was founded in 1995 (Malighetti et al., 2009). The major breakthrough of the low-cost model in Europe with strong growth in passenger volume took place in the decade from 2000 to 2010 despite the negative 
effect of 9/11 (Dobruszkes, 2006), going hand-in-hand with the diffusion of the internet (Internet World Stats, 2018). Legacy carriers have been strongly hit by 9/11 and especially US carriers and long-haul carriers were affected.

LCC are of special importance to the history of airline distribution as their internet-only distribution approach allowed them to act completely independent from the GDS world that the FSC were locked-into (Piga and Filippi, 2002). Being new entrants, they could apply a greenfield approach to the design of their airline IT systems resulting in ticket-free ARS and the use of dynamic pricing (Malighetti et al., 2009). Ticket-free reservation systems proved to be able to handle large passenger volumes in point-to-point operations that are typical for LCC operations.

Usually not being present in the GDS, the only way to purchase a ticket from a LCC is via the internet, a call centre (against charge) or a ticket counter (against charge). The exclusive availability of low-cost fares via the internet has had large consequences for airline distribution (Takač et al., 2006). In Europe, with Ryanair and Easyjet operating enormous passenger volumes without being booked via the GDS (at least to a big extend), the pre-dominant role of the GDS to be a one-stop-shop for airline sales was challenged. There have been approaches made by GDS providers to integrate LCC into the GDS display (e.g. Easyjet using Amadeus Light Ticketing) to re-aggregate the overall airline offer (Amadeus, 2018). However, the main volume share of LCC remained on their proprietary airline websites. The non-presence of a relevant part of the offer in the GDS triggered the development of technology providers offering aggregation of low-cost fares via an application programming interface (API) technology. Moreover, the disaggregation (i.e. Ryanair used a PSS system not connected to the GDS and thus the search was split into internet and GDS search to get a full market picture) being introduced by the LCC paved the way for the appearance of internet-based metasearchers aggregating classical GDS content and low-cost fares into a coherent search display. This underlines that even though GDS providers have built in-depth knowledge on efficient aggregation, they are no longer the single point of truth - aggregation can be realized via the internet (LSE Consulting, 2016).

The high share of direct bookings through airline websites allows airlines in search for differentiation to get more customer-specific data than via the GDS, enabling the airlines to provide tailored offers to their customers that increase their willingness-to-pay (Wittman and Belobaba, 2018). This is also consistent with Gures et al. (2018) that underline the importance of user-friendly, functional self-service opportunities.

Concisely, the rise of LCC has transformed the distribution landscape. Since many LCC with large passenger volumes are not present in the GDS, this challenges the GDS as being the single point of truth for airline distribution. The disaggregation of the GDS content has started earlier than the introduction of new distribution concepts that we will cover later in this chronological account. Aggregation has shifted to a meta-level integrating different distribution channels.

\section{Turning point 7: the advent of cloud computing}

The advent of cloud computing has been another critical turning point in the history of airline distribution (Vagdevi and Guruprasad, 2015). The idea of distributing services via a network of cloud servers rather than via a single high-performance mainframe has opened new opportunity windows to airline distribution and many other industries (Avram, 2014).

Building and maintaining a centralised proprietary GDS structure is connected to high initial investments and high entry barriers. Cloud computing can lower the entry barrier of distribution technology, significantly (Vagdevi and Guruprasad, 2015). With scalable services such as Amazon Web Services, even smaller-sized companies with limited financial funds have access to significant computing power and can scale their activities as dictated by market demands (Avram, 2014). This is important to mention as it facilitates innovative start-ups and digital giants to enter the field of airline distribution more easy than ever before. In addition, the possibility to offer travel agents a cloud-based web-service to access services related to airline distribution without any proprietary devices installed in the travel agency will enable travel agencies to connect to airlines and other distribution partners by other means than just a GDS. One important argument is that through cloud services there is no specific hardware needed, anymore. 
Travel agencies do not need proprietary terminals including hardware setup - they can access the offers of a new entrant with a cloud-based Software-as-a-Service (SaaS) from a computer with a standard internet browser, decreasing the resistance to change from a travel agency perspective. The aggregation of different airlines, hotels, rental cars and services can be provided from the cloud of a GDS provider but also by any other cloud-based SaaS provider that is able to provide the necessary aggregation service.

Briefly, cloud computing has lowered the entry barriers for substitutes to conquer the GDS.

\section{Turning point 8: American Airlines Direct Connect in the USA - the first wave}

In 2011, American Airlines - in an attempt to lower GDS fees - created a competing ticket delivering system, called "AA Direct Connect" (Bilotkach et al., 2014). The system was meant to bypass the existing GDS distribution connecting travel agents directly to American Airlines servers using the platform of new entrant Farelogix. This move by American Airlines provoked foreseeable reactions in the marketplace. In retaliation of the events, two major OTAs (Expedia and Orbitz) stopped displaying fares of American Airlines during the first quarter of 2011. Moreover, Sabre, the largest GDS in the US market (and the company whose technology has been developed by American Airlines and IBM) announced to display American Airlines worse than its airline competitors who did not follow American Airline's strategy (Bilotkach et al., 2014).

In April 2011, American Airlines filed a lawsuit with Expedia, Orbitz and Sabre that was settled outside court in favour of American Airlines (Reuters, 2012). This settlement has laid the foundation for all further activities as it proved those wrong who saw Sabre as the clear winner of this power play "GDS vs Airline". This legal success did not close the technological debate nor the commercial debate on whether a Direct Connect is advantageous or not. One major argument in this context was to point out that with Direct Connect the industry is going back to the complexity of the CRS era (the source of this complexity is described in detail in turning point 3).

\section{Turning point 9: IATA's NDC initiative}

The IATA has formally adopted its initiative New Distribution Capability (NDC) in 2012 at the World Passenger Symposium held in Abu Dhabi (Brecke and Steppler, 2013). The NDC standard has been published as "IATA Resolution 787 on enhanced airline distribution". It has been presented as the foundation to realise a new shopping experience for the airline product across all distribution channels. In doing so, NDC is extending the capabilities of airline websites to all sales channels (Westermann, 2013). Jäckel and Maier (2016) see NDC as a way "to position the airline in the centre of an interactive offer-generation process". Indeed, NDC shifts the offer creation process from within the GDS back to the airlines. In NDC, the airline combines all product elements to an airline offer and distributes it. In the GDS world, the airline feeds distinct components such as schedules, availabilities and fares directly (e.g. direct inventory link) or via partners (e.g. OAG, ATPCO) to the GDS providers who then combine it to an offer. Schulz (1996) states that the GDS "have been called inflexible dinosaurs not being able to fulfil current or future market needs. Criticism mainly relates to the insufficient scope of services offered and the high distribution costs". The notion of perceived insufficient scope of services is an important background for the intention to shift back the offer creation from the GDS to the airline. Concerning distribution cost, Nabais et al. (2018) have applied a game theory approach to evaluate potential strategies given different distribution channels. They find that dependent on the GDS cost it might make sense for airlines to keep or discard the GDS. Moreover, NDC and a Direct Connect environment facilitate the shift towards a dynamic pricing as the implementation of dynamic pricing in the existing GDS setting would call for new specifications (Dezelak and Ratliff, 2018; Vinod et al., 2018). This is in line with Oancea and Horgas (2018) who underline that NDC will redefine the travel experience and the way airlines manage and optimise their revenues. One specific field that is a pain-point to premium airlines is the field of ancillary services. As premium airlines need to differentiate their offer, the speed-to-market for offering ancillary services is crucial (Avram, 2017). Selling ancillary services has proven to be of value to many airline customers (O'Connell and Warnock-Smith, 2013; Wittmer and Rowley, 2014; Scotti et al., 2016). 
Airlines usually offer ancillary services first on their own airline websites as they have full control of the offer in this channel. In consequence, they do not harmonise these ancillary services (as they are meant to differentiate) with other airlines.

The GDS providers, in contrast, are seeking to make the different airline offers as comparable as possible in order to reduce the search complexity for the travel agents. Thus, they have a natural interest to support only the development of those ancillary services that are implemented by multiple carriers hosted in their systems. For the case of ancillary services it is obvious that there is a conflict of interest between being as much differentiated as possible (airline need) and standardizing as much as possible (GDS need).

As NDC is a standard (i.e. not a software or product), it needs technology partners that are developing products based on the standard (Bingemer, 2018). These partners can either be the GDS but also new entrants to the field of distribution. For new entrants (e.g. Direct Connect providers), NDC is very interesting as it defines a standard that can be used to harmonise the messaging for all Direct Connect airlines thus reducing complexity to the travel agency if the standard is implemented in its essential parts. This is why Direct Connect and NDC are closely coupled in most of the expert discussions. Bingemer (2018) underlines that the NDC standard is not yet mature and that it is not fully implemented by most of the players in the distribution landscape. Once this is the case, the aggregation of different contents will become much easier. In the market, more and more players seek for NDC level 3 certification thus fostering convergence to the NDC standard.

\section{Turning point 10: Direct Connect in Europe - the second wave}

In 2015, the Direct Connect development from the USA spilled over to Europe with Lufthansa Group announcing the introduction of a Distribution Cost Charge and the implementation of a Direct Connect API exempt from this charge (May, 2015). This led to significant market pressure and a heated discussion between Lufthansa Group and the travel agency landscape (BCD, 2015). Of course, Lufthansa's move was seen in context of the American Airline Direct Connect initiative given that Lufthansa was using the same technology partner as American Airlines to realise its Direct Connect and knowing that the lawsuit against Sabre was settled in favour of American Airlines. In July, British Airways announced to provide an NDC API to the agency landscape (Newcombe, 2015).

Despite similarities to the American Airline case, this second wave of Direct Connects was also different to the first wave. Different to the US market, after three years major competitors, i.e. British Airways and Air France, had joined the approach to lever a GDS fee to compensate their distribution cost and to offer an NDC API at the same time (Davis, 2017; Taylor, 2017). This was supported by the growing importance of the NDC standard. If the NDC standard is completely implemented, it provides travel agencies with "one plug" to connect multiple Direct Connects at a time. In practice, the NDC standard does not hold up with the idea of "one plug" as it suffers from incoherent implementation (Bingemer, 2018).

Another difference is the communication focus on "innovation in the distribution arena" that dominated the debate among market players. The discussion on Direct Connect and NDC has shifted from the question whether an alternative to the GDS is needed to the question how airline distribution needs to change in the context of digitalization.

\section{Turning point 11: cloud-based aggregation facilitates Direct Connects}

This and the last turning point are providing projections into the future to come. In the current environment, Direct Connects are an individual development per airline (see also turning point 10). Each airline is offering an own interface (API) and defines own process flows to access its data and workflows. This multitude of Direct Connect implementations leads to a lack of diffusion among travel agencies as each Direct Connect implies investment in connecting a specific NDC adapter (Bingemer, 2018). One major turning point in future will be the adoption of Direct Connect distribution into the solution portfolio of GDS providers. This turning point is crucial as it determines reach and diffusion of NDC-based Direct Connects. Without aggregation, it gets too 
expansive for providers to connect each market player, slowing down the diffusion process of the new NDC standard. This development is not about technology only - aggregation of NDC-based Direct Connects would imply a change of the established GDS business model (at least for the aggregation part). The standard GDS business model is a commercial model paid by airlines. In LCC aggregation, the travel agency is paying for the aggregation of different contents. An additional scenario in the aggregator segment is that cloud-based aggregators might emerge that would be able to provide travel agencies with content and booking capability from multiple sources (e.g. airlines, hotels, rental cars, cruise, GDS as well as other aggregators and agents). In the market, although first tendencies into this direction can be stated, we do not observe a broad diffusion of such technologies. Strauss (2017) argues that the diffusion of such models is hindered by technological and commercial reasons. Especially GDS providers struggle as a new aggregation approach would offend the existing business model that has been established over the years (Cheng, 2010). In an intermediate future, NDC-based blockchain technologies might be able to organise aggregation services similar to the GDS but at much lower cost. Such a blockchain might be used to organise the data storage for the whole travel chain, allowing selected providers to access relevant travel data of a traveller. Artificial intelligence (Al) will have a strong impact on the aviation industry (Jenner, 2017b). Especially in the field of airline search Al bears the potential to lower cost by applying intelligent search in order to lower the number of results retrieved via Direct Connects. The combination of these technologies has the potential to quickly outpace current GDS technology.

\section{Turning point 12: Internet of Things (IOT) as a driver of NDC APIs}

IOT is probably one of the most influencing technological developments of the future to come (Gasiorowski-Denis, 2016). The trend to integrate internet connection into items that have not been online before accelerates the need to easily access services via external APIs. Despite being often discussed in industrial settings, it is foreseeable that loT will play a major role in the future of tourism: Drones that take images, paper-free check-in services, self-service car rental, concierge services from the fridge in our holiday apartment - there is a multitude of applications that is perfectly suited for tourism application. If those singular loT services are linked into a network that is characteristic for a specific traveller, a standard or system is needed that can manage traveller IDs, travel data, location data, payment data, personal data, preference data, items and activities in one logic framework. Whilst the GDS-based PNR system is perfectly suited for air travel, it is less suited for the internet economy to come. In consequence, the growing application of loT technologies and their application in the tourism industry will drive the need to change to a more flexible distribution standard. This standard or system needs to be flexible enough to support applications not only in the field of travel and tourism but in all fields that touch the travel experience. Again, being much closer to internet applications, NDC and Direct Connect are perfectly suited for this future.

\section{Discussion}

Overviewing the critical turning points, we now use Anderson and Tushman's (1990) work to analyse systematically what can be derived out of the past for the future to come. Anderson and Tushman (1990) define a dominant design as "a single architecture that establishes dominance in a product class". Christensen et al. (1998) define a dominant design as the specification that defines the product category's architecture. Practical examples for dominant designs are, e.g., the DVD players, VHS video, cement, glass and microcomputers (Anderson and Tushman, 1990; Srinivasan et al., 2006). In their work, they describe a cyclical model of technological change: a dominant design develops out of a design competition and leads to a period of relative stability. After a dominant design has been established, only small adoptions are made to the dominant design (Anderson and Tushman, 1990). The formation of a dominant design is discussed as being a key event in the evolution of an industry (Utterback and Abernathy, 1975). This "era of incremental change" ends with a technological discontinuity (e.g. an important innovation) and an "era of ferment" (Anderson and Tushman, 1990) begins. In this era, multiple designs might co-exist until a new dominant design emerges (and so on). 
The history of airline distribution is very well suited to study the emergence and the disruption of a dominant design. In the early beginning of commercial air traffic (before turning point 1), air traffic was full of manual operations on a "paper and pencil" mode. The growing passenger volumes (turning point 1) forced the first technological discontinuity, the development of the ARS (turning point 2). As modelled by Anderson and Tushman (1990), an era of ferment can be observed throughout turning point 3 that is followed by the emergence of the GDS as a dominant design (turning point 4). After this turning point we see clear signals for a persisting dominance of the GDS (until turning point 8). The birth and diffusion of the internet (turning point 5), the rise of the LCC (turning point 6) and the advent of cloud computing (turning point 7) together have paved the way to another phase of technological discontinuity. The technological discontinuity is observable in American Airline's Direct Connect move (turning point 8) that has initiated the change away from incremental change. With IATA's NDC (turning point 9) and the second wave of Direct Connect activity in Europe (turning point 10) GDS were challenged in an ever stronger fashion. Despite still being dominant from a market power perspective, the status of the GDS being a dominant design is degrading. Following Anderson and Tushman's (1990) model, airline distribution has entered another era of ferment (around turning point 10) that is characterised by a competition of different designs that can substitute each other. We identify Direct Connects, GDS and aggregation approaches to be those co-existing designs consistent with our chronological account.

It is difficult to state where airline distribution might be headed to, but one thing seems obvious: it will not return to its very past. One commonly used argument is that a Direct Connect between travel agencies and airline would bring inefficiency as it would return the industry to turning point 3 (era of the CRS). Drawing on the critical turning point analysis and on the model of Anderson and Tushman (1990), we conclude that airline distribution enters indeed another era of ferment (like in the ARS/CRS phase) but that this era of ferment is not the same but a new one. In fact, internet technology and LCC with internet-only business models have completely changed the picture of the distribution landscape. In the early times of the CRS era, there was no way to aggregate different CRS systems in an efficient manner apart from a central server setup like the GDS. Today, internet technology allows to aggregate different offers from different sources in an efficient manner based on decentralised technology. Thus, despite the fact that a Direct Connect can be seen as a disaggregation from a technical point of view, it does not mean a return to the CRS era as new technologies have compensated weaknesses of the past (i.e. aggregation can be performed also in a decentralised fashion).

Another conclusion from the critical turning point analysis is that assuming the GDS still do reflect the totality of all flights is not correct, anymore. Of course, GDS do still provide the largest single source of airline content. Especially for intercontinental flights, the GDS cover almost all available connections. For continental flights, e.g. in Europe, with LCC doing huge sales volumes outside of the GDS, we see the GDS breaking away as a single point of truth. In turn, this does not mean that there is no future for the GDS - but they will need to change. In turn, the growing number of NDC Direct Connects needs to mature as well and need to adopt further responding to the multiple market needs.

As an outcome, we might expect a new dominant design to come. As Srinivasan et al. (2006) point out dominant designs are dependent on product and market characteristics. In some cases, it might happen that dominant designs do not emerge at all. However, given that we have seen some dominant designs emerging in airline distribution, we are waiting for the next dominant design to come. Turning points 11 and 12 provide some ideas what critical turning points might be lying ahead of the industry. As described in turning point 11, an adoption of the NDC standard by GDS and aggregators would increase the sales volume that is handled via Direct Connects and would give back power to the supplier side (Jenner, 2017a). This turning point might lead to a much broader application of NDC and Direct Connect technologies. The major problem field of NDC and Direct Connect is market diffusion not technological feasibility. Of course, GDS have a strong incentive to protect their proprietary developments. Given the digitalization, there is no way around to establish a new standard that is applicable as well for the non-aviation world thus allowing to connect all sources around a travel event. However, diffusion is key for commercial success. Currently, GDS have a strong interest to keep their systems running and travel agents do not yet have a "one plug" solution that allows us to connect to multiple airlines at a time thus reducing cost for the technical connection to their own systems. 
Turning point 12 describes a future with a high usage of loT technologies. Those technologies call for a standard that is flexible and easy to handle. Castiglioni et al. (2018) suggest a trend towards airline virtualization. Such a development would further support the tendencies described in turning point 12 as airlines in this case would need to develop the capacity to interact with one another in a network setting in order to manage this virtualization smoothly to obtain the best customer journey. One major concern is that airlines, in order to lever the potential of such a distribution system, first need to internally connect their proprietary IT solutions in order to be able to provide the ancillary products smoothly, that they are already able to sell via NDC-based Direct Connects.

Even though turning points 11 and 12 are lying in the future and are not reached yet, the travel industry should prepare itself for these critical turning points to come. Suki and Suki (2017) argue that airlines should consider technological advantages if they wish to become more competitive.

\section{References}

Akin, J. (2018), "IoT: centralized vs distributed architectures", Network Computing, available at: www. networkcomputing.com/networking/iot-centralized-vs-distributed-architectures/435583941 (accessed 18 May 2018).

Alamdari, F. and Mason, K. (2006), "The future of airline distribution", Journal of Air Transport Management, Vol. 12 No. 3, pp. 122-34, doi: 10.1016/j.jairtraman.2005.11.005.

Alonso, C.J. (2010), "The history of the future", Romanic Review, Vol. 101 Nos 1-2, pp. 101-04.

Amadeus (2018), "Amadeus light ticketing”, available at: www.amadeus.com/web/amadeus/en_CC-CC/ Travel-agencies/Our-portfolio/Connect/Content/CC_EN_Amadeus-Light-Ticketing (accessed 18 May 2018).

Anderson, P. and Tushman, M. (1990), "Technological discontinuities and dominant designs: a cyclical model of technological change”, Administrative Science Quarterly, Vol. 35 No. 4, pp. 604-33.

Avram, B. (2017), "Ancillaries in the aviation industry. Importance, trends, going digital", Expert Journal of Marketing, Vol. 5 No. 2, pp. 53-65.

Avram, M.-G. (2014), "Advantages and challenges of adopting cloud computing from an enterprise perspective”, Procedia Technology, Vol. 12, pp. 529-34, doi: 10.1016/j.protcy.2013.12.525.

BCD (2015), "Lufthansa Group's DCC promises added costs, lost productivity", move, BCD Travel, Utrecht, available at: www.bcdtravel.com/move-dk/lufthansa-groups-dcc-promises-added-costs-lost-productivity/ (accessed 18 May 2018).

Bießlich, P., Wegmann, K., Lütjens, K. and Gollnick, V. (2018), "A hierarchical metamodeling approach for airline costs", Journal of Air Transport Management, Vol. 71, pp. 193-200, available at: www.sciencedirect.com/ science/article/abs/pii/S096969971830142X

Bilotkach, V., Rupp, N. and Pai, V. (2014), "Value of a platform to a seller: case of American airlines and online travel agencies", Working Paper No. 13-08, NET Institute, pp. 1-32, available at: www.netinst.org/

Bingemer, S. (2018), "IATA NDC and direct connect: opportunities and challenges for travel agencies and airlines", ITB Congress 2018, Berlin, pp. 1-29, available at: www.itb-kongress.de/media/itbk/itbk_dl_all/itbk_ praesentationen2018/ITB_Workshops_Day_1_NDC_And_Direct_Connect_Opportunities_And_Challenges_ For_Airlines_And_Travel_Agents_Prof._Dr._Stephan_Bingemer.pdf (accessed 15 May 2018).

Boyd, E.A. (2006), "Revenue management in the airline industry: from gumball dispensers to rocket science", Journal of Revenue and Pricing Management, Vol. 5 No. 2, pp. 157-66.

Brecke, K. and Steppler, U. (2013), “IATA's New Distribution Capability (NDC): a revolution?”, Air \& Space Law, Vol. 38 No. 6, pp. 487-96.

Brownlow, N. (2006), "Is there a future for global distribution systems?", InterVISTAS' Canadian Aviation Intelligence Report, 15 June, pp. 12-13, available at: www.intervistas.com/downloads/CAIR/articles/06_ jun2006_c.pdf (accessed 30 September 2018).

Carey, R., Kang, D. and Zea, M. (2012), "The trouble with travel distribution”, available at: www.mckinsey. com/industries/travel-transport-and-logistics/our-insights/the-trouble-with-travel-distribution (accessed 21 July 2018). 
Castiglioni, M., Gallego, A. and Galán, J. (2018), "The virtualization of the airline industry: a strategic process", Journal of Air Transport Management, Vol. 67, pp. 134-45, doi: 10.1016/j.jairtraman.2010.04.002.

CERN (2018), "Tim Berners-Lee's proposal”, available at: http://info.cern.ch/Proposal.html (accessed 18 May 2018).

Cheng, K. (2010), "Evaluation of US legacy airline distribution strategies", Journal of Air Transport Management, Vol. 16 No. 6, pp. 337-9, doi: 10.1016/j.jairtraman.2010.04.002.

Christensen, C., Suárez, F. and Utterback, J. (1998), "Strategies for survival in fast-changing industries", Management Science, Vol. 44 No. 12, pp. 207-20, doi: 10.1287/mnsc.44.12.S207.

Davis, P. (2017), "Air France-KLM confirms GDS fee”, Travel Weekly, 3 November, available at: www. travelweekly.co.uk/articles/291369/air-france-klm-confirms-gds-fee (accessed 18 May 2018).

Debbage, K. and Delk, D. (2001), "The geography of air passenger volume and local employment patterns by US Metropolitan Core Area: 1973-1996”, Journal of Air Transport Management, Vol. 7 No. 3, pp. 159-67, doi: 10.1016/S0969-6997(00)00045-4.

Decker, M. (2004), Structures et stratégies des compagnies aériennes à bas coûts, L'Harmattan, Paris.

Dezelak, M. and Ratliff, R. (2018), "Towards new industry-standard specifications for air dynamic pricing engines", Journal of Revenue and Pricing Management, 28 March, pp. 1-9 (in press).

Dobruszkes, F. (2006), "An analysis of European low-cost airlines and their networks", Journal of Transport Geography, Vol. 14 No. 4, pp. 249-64, doi: 10.1016/j.jtrangeo.2005.08.005.

Duch-Brown, N., Grzybowski, L., Romahn, A. and Verboven, F. (2017), "The impact of online sales on consumers and firms. Evidence from consumer electronics", International Journal of Industrial Organization, Vol. 52 No. 3, pp. 30-62, doi: 10.1016/j.jijndorg.2017.01.009.

Field, D. and O'Toole, K. (2004), "Where next for the GDS?", Airline Business, Vol. 20 No. 3, pp. 34-43.

Field, S. (2016), "Southwest airlines and the impact of low-cost carriers on airline ticket prices", FUSIO, Vol. 1 No. 1, pp. 1-23.

French, T. (1998), "The future of global distribution systems", Travel \& Tourism Analyst, No. 3, pp. 1-17.

Gasiorowski-Denis, E. (2016), "How the Internet of things will change our lives", International Organisation for Standardization (ISO), Geneva, available at: www.iso.org/news/2016/09/Ref2112.html (accessed 30 August 2018).

Gnutzmann, H. and Spiewanowski, P. (2016), "Did the Lufthansa group GDS surcharge stimulate direct online sales? A causal analysis", e-Review of Tourism Research, Vol. 7, pp. 1-6.

Gures, N., Inan, H. and Arslan, S. (2018), "Assessing the self-service technology usage of Y-Generation in airline services”, Journal of Air Transport Management, Vol. 71, pp. 215-19, doi: 10.1016/j.jairtraman.2018.04.008.

Hill, M. (2016), "How and how much do travel agents get paid?", Gifted Travel Network, Inc., Mooresville, available at: www.giftedtravelnetwork.com/much-travel-agents-get-paid (accessed 21 July 2018).

Internet World Stats (2018), "Internet growth statistics: history and growth of the internet from 1995 till today", available at: www.internetworldstats.com/emarketing.htm (accessed 18 May 2018).

Jäckel, K. and Maier, L. (2016), "IATA's new distribution capability and its impact on traditional forms of cooperation in the airline industry", International Journal of Aviation Management, Vol. 3 No. 4, pp. 266-94, doi: 10.1504/IJAM.2016.10009086.

Jenner, G. (2017a), "Realising a digital travel retail dream: IATA is widening its scope beyond NDC, potentially giving control to carriers by ending dominance of complicated product delivery systems optimised for the pre-internet age", Flight Airline Business, Sutton, pp. 40-3.

Jenner, G. (2017b), "First steps with Al herald disruptive time for airlines", available at: www.wearefinn.com/ topics/posts/first-steps-with-ai-herald-disruptive-time-for-airlines/ (accessed 30 August 2018).

Jonas, D. (2013), "Vision 2020: Old dogs, New Tricks and Future of GDSs", Business Travel News, 11 November, available at: www.businesstravelnews.com/Business-Travel-Agencies/Vision-2020-OldDogs-New-Tricks-And-The-Future-Of-GDSs (accessed 6 August 2018).

Kaplan, D. and Dayton, M. (1988), "Policies for the deregulated airline industry", United States Congress, Washington, DC, 1988-7, pp. 1-84. 
Kärcher, K. (1996), "The four global distribution systems in the travel and tourism industry", Electronic Markets, Vol. 6 No. 2, pp. 20-4.

LSE Consulting (2016), "Travel distribution: the end of the world as we know it?", available at: www.amadeus. com/documents/reports/lse-report-travel-distribution-the-end-of-the-world-as-we-know-it.pdf (accessed 18 May 2018).

Malighetti, P., Paleari, S. and Redondi, R. (2009), "Pricing strategies of low-cost airlines: the Ryanair case study", Journal of Air Transport Management, Vol. 15 No. 4, pp. 195-203, doi: 10.1016/j. jairtraman.2008.09.017.

May, K. (2015), "Lufthansa to add surcharge to every booking made via the GDS", tnooz, 2 June, available at: www.tnooz.com/article/lufthansa-to-add-surcharge-to-every-booking-made-via-the-gds/ (accessed 19 May 2018).

Nabais, P., Dias, M. and Jorge, S. (2018), "The new distribution capability in the airline industry: a game theory approach", Revista Turismo \& Desenvolvimento, Vol. 2 Nos 27/28, pp. 413-4.

Newcombe, T. (2015), "BA opens up flight data as part of NDC pilot", BBT - Buying Business Travel, available at: https://buyingbusinesstravel.com/news/1324425-ba-opens-flight-data-part-ndc-pilot (accessed 19 May 2018).

Oancea, O. and Horga, R. (2018), "The new wave of airline revenue and pricing management - what next for the leisure customer?”, Journal of Revenue and Pricing Management, Vol. 17 No. 3, pp. 182-8.

O'Connell, J.F. and Warnock-Smith, D. (2013), "An investigation into traveler preferences and acceptance levels of airline ancillary revenues", Journal of Air Transport Management, Vol. 33, pp. 12-21, doi: 10.1016/j. jairtraman.2013.06.006.

Oxley, D. and Jain, C. (2015), "Global air passenger markets: riding out periods of turbulence", World Economic Forum - Travel \& Tourism Competitiveness Report, Davos-Klosters, Switzerland, 21-24 January, pp. 59-61.

Piga, C. and Filippi, N. (2002), "Booking and flying with low cost airlines", International Journal of Tourism Research, Vol. 4 No. 3, pp. 237-49, doi: 10.1002/jtr.379.

Plugge, W. and Perry, M. (1961), "American Airline's 'Sabre' electronic reservation system”, Proceedings of the IRE-AIEE_ACM '61 computer conference, Los Angeles, CA, pp. 593-602.

Quinby, D. (2009), "The role and value of global distribution systems in travel distribution”, Phocuswright Inc, Sherman and New York, NY, November, available at: www.deplacementspros.com/attachment/180441 (accessed 6 August 2018).

Reuters (2012), "American airlines, Sabre settle legal dispute", Reuters, 1 November, available at www. reuters.com/article/us-americanair-sabre-idUSBRE89U1RY20121031 (accessed 18 May 2018).

Sabre (2018), "The Sabre Story", available at: www.sabre.com/files/Sabre-History.pdf (accessed 18 May 2018).

Schmitt, D. and Gollnick, V. (2016), Air Transport Systems, Springer, Vienna, doi: 10.1007/978-3-7091-1880-1.

Schulz, A. (1996), "The role of global computer reservation systems in the travel industry today and in the future”, Electronic Markets, Vol. 6 No. 2, pp. 17-20.

Scotti, D., Dresner, M. and Martini, G. (2016), "Baggage fees, operational performance and customer satisfaction in the US air transport industry", Journal of Air Transport Management, Vol. 55, pp. 139-46, doi: 10.1016/j.jairtraman.2016.05.006.

Sion, B., Mihălcescu, C. and Mărginean, A. (2013), "The passage from airline reservation systems to global distribution systems”, Journal of Information Systems \& Operations Management, Vol. 7 No. 1, pp. 93-104.

Sismanidou, A., Palacios, M. and Tafur, J. (2009), "Progress in airline distribution systems: the threat of new entrants to incumbent player", Journal of Industrial Engineering and Management, Vol. 2 No. 1, pp. 251-72, doi: 10.3926/jiem.2009.v2n1.p251-272.

Smith, B., Gunther, D., Roa, V. and Ratliff, R. (2001), "E-commerce and operations research in airline planning, marketing and distribution", Interfaces, Vol. 31 No. 2, pp. 37-55.

Srinivasan, R., Lilien, G. and Rangaswamy, A. (2006), "The emergence of dominant designs", Journal of Marketing, Vol. 70 No. 2, pp. 1-17. 
Strauss, M. (2017), “The reality behind NDC: Why NDC won't break down the GDS oligopoly - yet”, Travel Industry Blog, available at: www.travel-industry-blog.com/travel-industry/ndc/ (accessed 30 August 2018).

Suki, N. and Suki, N. (2017), "Flight ticket booking app on mobile devices: examining the determinants of individual intention to use", Journal of Air Transport Management, Vol. 62, pp. 146-54, doi: 10.1016/j. jairtraman.2017.04.003.

Takač, A., Babić, R. and Vidović, A. (2006), "An analysis of traditional airlines' responses to low cost carriers' pricing models", 10th International Conference on Traffic Science Transportation and Globalization ICTS, pp. 1-12.

Taylor, I. (2017), "BA-Iberia to add GDS fee next week", Travel Weekly, 27 October, available at: www. travelweekly.co.uk/articles/290872/ba-iberia-to-add-gds-fee-next-week (accessed 18 May 2018).

Tyagi, J. (2014), "Airline ticket booking", International Journal of Advanced Technology in Engineering and Science, Vol. 2 No. 11, pp. 84-7.

Utterback, J.M. and Abernathy, W. (1975), "A dynamic model of process and product innovation", Omega, Vol. 3 No. 6, pp. 639-56.

Vagdevi, P. and Guruprasad, H. (2015), "A study on cloud computing in aviation and aerospace”, International Journal of Computer Science and Engineering Technology, Vol. 6 No. 3, pp. 94-8.

Vinod, B., Ratliff, R. and Jayaram, V. (2018), "An approach to offer management: maximizing sales with fare products and ancillaries", Journal of Revenue and Pricing Management, Vol. 17 No. 2, pp. 91-101, doi: 10.1057/s41272-017-0121-1.

Westermann, D. (2013), "The potential impact of IATA's new distribution capability (NDC) on revenue management and pricing", Journal of Revenue \& Pricing Management, Vol. 12 No. 6, pp. 565-8, doi: 10.1057/rpm.2013.23.

Wittman, M. and Belobaba, P. (2018), "Customized dynamic pricing of airline fare products", Journal of Revenue and Pricing Management, Vol. 17 No. 2, pp. 78-90, doi: 10.1057/s41272-017-0119-8.

Wittmer, A. and Rowley, E. (2014), "Customer value of purchasable supplementary services: the case of a European full network carrier's economy class”, Journal of Air Transport Management, Vol. 34, pp. 17-23, doi: 10.1016/j.jairtraman.2013.07.002.

Yeoman, I.S. and McMahon-Beattie, U. (2017), "The turning points of revenue management: a brief history of future evolution”, Journal of Tourism Futures, Vol. 3 No. 1, pp. 66-72, doi: 10.1108/JTF-11-2016-0040.

\section{Corresponding author}

Stephan Bingemer can be contacted at: stephan.bingemer@ism.de

For instructions on how to order reprints of this article, please visit our website: 